\title{
心基について
}

\section{玉 井威}

こてで「心基」というのは，言うまでもなく，パーリ仏教で立てる色法の一種 hadayavatthu のてとで，心の物質的な所依となっているとてろのものである。 こらいった意味の心基がいかにして成立したかというととを中心にして, 以下若 干の考察をしてみたい。

考察する手順として，まず hadaya からみていこう。As. (p. 140) に hadaya に は三義があるてとが説かれている。即ち，1）胸 (ura)，2）心 (citta)，3）心藏 (hadayavatthu) の三である。そしてその三のそれぞれにニカーヤにおける用例が 引かれている。例えば，三十二身分の一として hadaya が挙げられる場合は，心 臓 (hadayavatthu) の意味であり，また，このAs. の箇所は citta の同義語の一で ある hadaya を註釈する箇所であるが，その場合は内的（精神的）な義 (abbhantarațtha）によって，ててでは citta が hadaya と呼ばれているという。As. の記述 からみて，胸の義が心の義の換喻だとすれば，1）心としての hadaya と，2）心 蔵としての hadaya の二義にまとめられょう。しかし，てれら二義からも示唆さ れるように，また「心藏」といら漢語自体もそうであるように，心蔵は心の働き のあり場所としての，心的活動の座としての機能をもったものとしても認識され ていると考えられ，事実，Veda 文献にも既にそういった用例があり1)，インドの 伝統的・通俗的考えのようである。後に，パーリ阿昆達磨において心の所依とし て心基を要請するに至ったのも，一つにはてらいった孝えにも起因するであるら。

次に，その心基についてみていてう。Abhidh-s-ț. (ed. Rewatadhamma, p. 160) によると，「hadaya そのものが意界と意識界の所依であるととの基盤（vatthu）で あるから心基 (hadayavatthu) である」と。とてでいう hadaya はいわゆる臓器と しての心臓とみられるから，意界・意識界の活動する物質的基盤としての心臓が 心基であると解釈される。乙れは心的活動の座が心蔵にあるとするインドの伝統 的通俗説に基づいた語義解釈と言えよう。とてちが，更に続いて次のように言う， 「そしてそれは心蔵といら容器の中 (hadayakosabbhantara) にある半パサタ (aḍdhapasata 半合) ほどの血液に依止して転起する」(p. 100) と。てれによって, 意 界・意識界の活動する基盤は心臓そのものではなくて, 心臓の中にある血液にあ 


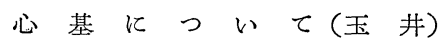

るととが知られる。しかし，更に厳密に言えば，心基は心色（hadayarūpa）こい ら一種の色法であっで2)，血液そのものでもないてとは注意す心゙きであろう。て の点を, Dhammapāla は次のように言っている3)。即ち, 依止の依止 (nissayanissaya) も依止（nissaya）と言われる。原因の原因（kāraṇakāraṇa）の場合にも慣用的 に単に原因 (kāraṇa) と言い，例えば「賊によって村が椀かれた」と言らようなも のだ，といら。つまりこれは直接的には「火によって村が焼かれた」と言うべき ところであろら。更にまた，色聚 (rūpakalāpa) 中に心基がある場合，それは血液 と共にあるものとしてのみ存続するから，「それ（血液）に依止して」と言われ た，と述べている。Moh.（p. 64）の言葉を借りれば，心基は血液中に「拡散して」 (vyăpetvā) あるもので，直接的にはそれに依止して意界・意識界の活動があるわ けである。

次にこのととをVism. 及びその註釈の記述に従って詳しくみていてら ${ }^{4)}$ 。まず Vism. (p. 447) は次のように言ら。

必基は意界・意識界の依止たることを相とし，それら〔二〕界の保持を作用とし、〔そ れらを」運ぶことを現状とし, 心臟中の血液に依止し, 保持等の作用をなす四大種によ って助成され，時節・心・食によって支持せられ，寿命によって守護せられ，意界・意 識界およびそれと相応する諸法の基盤たることを果しつつ在る。

Dhammapāla の註釈によれば5)，乙の事実は聖教 (āgama) と道理 (yutti) から， つまり教証と理証の二点から知られるといら。そして，教証としては Tikap.の 一節を引いている。即ち，「或る色に依止して意界及び意識界が転起するなら ば，その色は意界・意識界及びその相応の諸法の依止縁 (missayapaccaya) であ るから縁である」(p.4) というもので，そこではそこにいう「或る色」が何であ るかは特定していない。しかし，註釈家はてれを以て教証とするわけである。精 神活動の物質的基盤について述べたのは，この一節が初出のようであるが，も し，この色が心基のととを言っているのだとすると，一つの問題点が生じる。即 ち，最も網羅的に物質の分析を扱ら Dhs. の rūpakaṇḍ（色品）において，何故 に心基が説かれなかったかといらととである。その理由を註釈は教えの不差別 (desanābheda)，つまり教えに一貫性を保つためだと言っている。てれはどらいら ととかと言えば, Dhs. (pp. 125-6, pp. 149ff.) に「眼識の基である色があり，眼識の 基でない色がある。眼識の所縁である色があり，眼識の所縁でない色がある」と いらように眼識等の前五識のそれぞれについて，基 (vatthu) と所縁 (ārammaṇa) の二者一具が語られているが，意識については語られていない。註橎によれば, 
もし意識についても，「意識の基である色があり，意識の基でない色がある」と いうように基の二者一具が言われる場合でも，所縁の二者一具については，同様 には言えないという。つまり，「意識の所緑である色があり，意識の所緑でない 色がある」とは言うことができないといら訳である。てれは意識の場合，基の二 者一具は言いえても, 所縁については, 一切の色法は意識の所緑となる(Dhs. 969）とされているから，所縁の二者一具は言えないわけである。それ故に，意 識について，基二者一具と所縁二者一具が両立しないならば教えに一貫性 (ekarasa）を欠くことになるといら。つまり，前五識の場合の教えとの一貫性・統一性 である。そして註釈は「一貫性をもった形で，ててで教えを示すてとが師の意向 であった。そういう訳で心基がそて（Dhs.)で説かれなかったのであって，認め られていないからではない，と知るべきである」と結んでいる。要するに，心基 の省略は避け難いととであったということになる。Tikap. に説かれている「或る 色」が後に特定される「心基」を予想しているとみなすととは困難ではないが， Dhs. に心基が説かれなかった理由を教えの一貫性に帰す註釈の説明は，Karuna dasa 氏が言うように6)，極めて巧妙な説明の仕方ではあるが，真の理由ではない であろら。氏によれば，心基が Dhs. で説かれず，Tikap. 中では明言されず，後 に明言されるに至った理由はその歴史的プロセスに帰せられ，例えば，Tikap. の段階では，その著者が精神活動の座を構成するとてろのものに関して，完全に は確かではなかったのではないかとしている。穏当な見解と言えよう。

続いて道理 (yutti) といら点から心基の存在証明が試みられている。つまり, Tikap. 中で言われた「或る色」をパーリアビダンマで説くとてろの二十八の色 法のどれかとアイデンティファイする試みがなされているわけである。まず初め 飞，意界・意識界は，眼識界等における場合と同様，五蘊有 (pañcavokārabhava) つまり色と結ばれてある生存 (rūpapațibaddhavutti) においては, 決定色 (nipphannarūpa) 即ち業等起色 (kammasamuțthānarūpa) であって, かつ所造色 (upādārūpa) であるとてろの色法を所依として持つてとが確認される。従って，ての点から， 決定色ではあっても所造色ではない四大種は除かれ, 逆に所造色ではあっても決 定色ではない虚空界（ākāsadhātu）等の十の不決定色（anipphannarūpa）は所依と しては自動的に除かれる。すると残る十四の決定・所造色にしぼられるが，眼根 等の五も専一に眼識等の所依となるから，てれらも無条件に除かれ，色・声・ 香・味の四所縁（触は大種に摄せられる）と段食（食素 oja）は根に縛せられている もの (indriyabaddha 生物) の外にも生起しているてとが見られるから, 意界・意 
識界の所依たるとと (nissayatā) にはふさわしくない。男・女二根は，てれら二 つ共欠いた者（例えば半択迦 pandaka）にも二界は見られるから所依たるにふさわ しくない。また命根には特別の作用があるから所依としてはふさわしくない。す ると最後に心基が残るが，註釈は次のよらに言ら。「それ故に，残余からして心 基がそれらの所依であると知るべきである」と。てのよらに消去法によって，二 十八色の中から，意界・意識界の所依として最もふさわしいものを特定していく のである。この討議の主目的は，表面的には「或る色」を二十八色中のどれかと アイデンティファイするととにあるわけだが, Karunadasa 氏の言らよらに7), Dhs. 中に説かれた二十七色とは別の精神活動の物質的基盤として最もふさわし い単独の色法を新たに仮定するてとであり，その正当性を示すととにあったと言 えよう。なお，それが心臓といら場所 (hadayapadesa) において住しているとい らてとが，いかにして経験的に知られるかといら問題が残るが，それについては 註釈は次のよらに言っている。

[誰かある人が〕注意し心を傾け專心して何かを考えるとき，その人は心蔵に疲労を感 じることから，そこに住しているといらてとが知られる。

以上で，心基に関する主な議論は尽きるよらに思われる。因みに，心臓として の hadaya についてふれておてら。これについてはVism. (pp. 256-257) において, その hadaya の色, 形, 方位 (disā), 場所 (okāsa), 限界 (pariccheda) といった 点から詳細に述べられている。心基との関連から要点のみ記すと，心臓といらの は, 実は心臓の肉の部分 (hadayamamsa) のととであるといら。つまり臓器とし ての心蔵が hadaya と呼ばれるわけである。そしてその中に, 前述したよらに, 半パサタ程の血液が保持せられてあるのである。色は赤いと説かれているが，注 目すべきは行者によってその色が異なるとされている点である。例えば，貪行者 のは赤く, 德行者のは黒いといった具合である。痴, 尋, 信の各行者についても それぞれ述べ，最後に慧行者のは澄夕浄く濁りなく浄白（pandara）で遍浄で良質 の摩尼珠の如く光り輝いているという。これは心臓は赤いとする先程の生理学上 の客観的な記述とは趣きを異にし，倫理的宗教的視点が導入されているようで, Dhs. (p. 10) やVibh. (pp. 88-89) において心や意界の同義語の一つとして浄白 (panḍara) を挙げているのと同趣旨であろら。これは Mrs. Rhys Davids が述べて いるよらに8), 一つの倫理学上の隠喻であり, 本来清浄であるべきはずのものが, 客塵煩悩によって雑染せられているととを示しているとみられる。(註省略)

(同朋大学専任講師) 